\title{
Organic fertilization in the production and chemical composition of non-conventional leafy vegetables ${ }^{1}$
}

\author{
Deborah Sepini Batista ${ }^{2}$, José Ricardo Mantovani ${ }^{3}$, \\ Luis Felipe Lima e Silva ${ }^{3}$, Douglas Correa de Souza ${ }^{4}$, Paulo Roberto Corrêa Landgraf ${ }^{3}$
}

\begin{abstract}
Non-conventional leafy vegetables can be a good source of nutrients for the human diet, but there is little information on fertilization for these species. This study aimed to evaluate the effect of organic fertilization with cattle manure on the production and chemical composition of non-conventional leafy vegetables. The experiment was conducted in a greenhouse, in pots. The factors under study were non-conventional leafy species (Rumex acetosa, Stachys byzantina and Lactuca canadensis) and cattle manure doses $\left(0 ; 5 ; 10 ; 15\right.$; and $\left.20 \mathrm{t} \mathrm{ha}^{-1}\right)$, arranged in a $3 \times 5$ factorial scheme, in a randomized block design, with four replications. At harvest, the following parameters were evaluated: stem diameter; total number of leaves; number of leaves with commercial standard; shoot fresh and dry matter; macro and micronutrients concentration and accumulated amounts in the shoot. The fertilization with cattle manure altered the stem diameter, number of leaves with commercial standard, shoot fresh and dry matter, as well as the accumulation of the nutrients $\mathrm{N}, \mathrm{P}, \mathrm{K}, \mathrm{Ca}, \mathrm{Fe}, \mathrm{Mn}$ and $\mathrm{Zn}$ in the shoot of the three species studied. The additions obtained varied from 1.1 to 2.1 times, in relation to the treatment without organic fertilization, and the dose equivalent to $20 \mathrm{t} \mathrm{ha}^{-1}$ was the most adequate one. The organic fertilization with cattle manure increases the production and accumulation of nutrients in the non-conventional vegetables evaluated, with $R$. acetosa presenting a nutrient accumulation higher than S. byzantina and L. canadensis.
\end{abstract}

KEYWORDS: Rumex acetosa L., Stachys byzantina K. Koch, Lactuca canadensis L., cattle manure, non-conventional food plants.

\section{INTRODUCTION}

Non-conventional vegetables, also called nonconventional food plants, are plants that have one or more parts that can be consumed, such as fruits,

\section{RESUMO}

Adubação orgânica na produção e composição química de hortaliças folhosas não convencionais

As hortaliças folhosas não convencionais podem ser uma boa fonte de nutrientes para a dieta humana, mas há poucas informações sobre adubação para essas espécies. Objetivou-se avaliar o efeito da adubação orgânica com esterco bovino na produção e composição química de hortaliças folhosas não convencionais. O experimento foi conduzido em casa-de-vegetação, em vasos. Os fatores em estudo foram espécies de hortaliças não convencionais (Rumex acetosa, Stachys byzantina e Lactuca canadensis) e doses de esterco bovino $\left(0 ; 5 ; 10 ; 15\right.$; e $\left.20 \mathrm{t} \mathrm{ha}^{-1}\right)$, arranjados em esquema fatorial $3 \times 5$, em delineamento de blocos ao acaso, com quatro repetições. Na colheita, foram avaliados o diâmetro de caule, número total de folhas, número de folhas com padrão comercial, matéria fresca e seca da parte aérea, concentração e quantidades acumuladas de macro e micronutrientes na parte aérea. A adubação com esterco bovino alterou o diâmetro de caule, número de folhas com padrão comercial, matéria fresca e seca da parte aérea, bem como o acúmulo dos nutrientes N, P, K, Ca, Fe, Mn e Zn na parte aérea das três espécies estudadas. Os acréscimos obtidos variaram de 1,1 a 2,1 vezes, em relação ao tratamento sem adubação orgânica, e a dose equivalente a 20 t ha $^{-1}$ foi a mais adequada. A adubação orgânica com esterco bovino aumenta a produção e o acúmulo de nutrientes nas hortaliças não convencionais avaliadas, sendo que $R$. acetosa apresenta maior acúmulo de nutrientes do que $S$. byzantina e L. canadensis.

PALAVRAS-CHAVE: Rumex acetosa L., Stachys byzantina K. Koch, Lactuca canadensis L., esterco bovino, plantas alimentícias não convencionais.

flowers, leaves, tubers and seeds. They are native or exotic, with spontaneous growth (being frequently confused with weeds) or grown in a simple way, as they present little demand, in relation to cultivation techniques (Kinupp \& Lorenzi 2014).

${ }^{1}$ Received: Nov. 04, 2020. Accepted: Feb. 17, 2021. Published: Mar. 25, 2021. DOI: 10.1590/1983-40632021v5166508.

${ }^{2}$ Instituto Federal de Educação, Ciência e Tecnologia do Sul de Minas Gerais, Machado, MG, Brasil.

E-mail/ORCID: deborah.batista@ifsuldeminas.edu.br/0000-0001-8971-5974.

${ }^{3}$ Universidade José do Rosário Vellano, Alfenas, MG, Brasil. E-mail/ORCID: mantovanijr@yahoo.com/0000-0002-9817-8143, luis.silva@unifenas.br/0000-0002-6082-9182,paulo.landgraf@unifenas.br/0000-0002-2518-9159.

${ }^{4}$ Universidade Federal de Lavras, Departamento de Agricultura, Lavras, MG, Brasil.

E-mail/ORCID: douglascorrea@ymail.com/0000-0003-3956-1342. 
Non-conventional vegetables were very appreciated in the past, but they have gradually been devalued and become underutilized (Viana et al. 2015). However, these plants still represent a quality food alternative, as they have high levels of vitamins, minerals and fibers, in addition to antioxidant compounds (Viana et al. 2015, Silva et al. 2018b, Silva et al. 2019, Botrel et al. 2020).

Kinupp \& Barros (2008) found levels of protein and mineral salts, such as $\mathrm{P}, \mathrm{Ca}, \mathrm{Fe}$ and $\mathrm{Zn}$, in non-conventional vegetables higher than in commercial species of similar use, showing the high nutritional potential of these species.

In Brazil, there is a great diversity of nonconventional vegetable species. Among the leafy vegetables, Rumex acetosa L., Stachys byzantina K. Koch. and Lactuca canadensis L. have been gaining space and arousing the interest of producers and the consumer market (Silva et al. 2017, Silva et al. 2018a, Oliveira et al. 2019, Oliveira et al. 2020).

Organic fertilization is frequently used for growing vegetables (Peixoto Filho et al. 2013, Yagi et al. 2020). Cattle manure is one of the organic fertilizers most widely used in agriculture (Braos et al. 2015), and can provide improvements in aggregation, porosity, nutrient supply and increase in the soil cation exchange capacity (Alencar et al. 2015, Mantovani et al. 2017, Padilha Júnior et al. 2020).

The positive effects of organic fertilization with cattle manure on the growth and production of conventional vegetables are frequently reported in the literature (Peixoto Filho et al. 2013, Mantovani et al. 2017). However, for non-conventional vegetables, this subject is still poorly studied. Thus, in the cultivation of these species, adaptations of the fertilization recommended to conventional vegetables are common, or even the use of fertilization without technical criteria (Souza et al. 2018, Xavier et al. 2019).

In view of that, this study aimed to evaluate the effect of fertilization with cattle manure on the production and chemical composition of nonconventional leafy vegetables.

\section{MATERIAL AND METHODS}

The experiment was conducted in pots, in a greenhouse, in Machado, Minas Gerais state, Brazil, from November 2019 to March 2020.

A randomized block design was used, in a $3 \times 5$ factorial scheme, with four replications, totaling 60 experimental units. The treatments consisted of a combination of three non-conventional leafy vegetables (Rumex acetosa L., Stachys byzantina K. Koch. and Lactuca canadensis L.) and five doses of cattle manure, based on soil volumes equivalent to $0 ; 5 ; 10 ; 15$; and 20 tha $^{-1}$. Non-conventional vegetable species have been defined as having a similar cycle, and the used cattle manure doses are frequently recommended in vegetable cultivation (Raij et al. 1997, CFSEMG 1999).

A total of $350 \mathrm{dm}^{3}$ of a clayey soil, collected from the superficial layer $(0-20 \mathrm{~cm})$ and not used for cultivation for several years, was air-dried and shaded, ground, passed through a 4-mm mesh sieve and was sampled for an initial routine chemical analysis (Silva 2009) (Table 1).

The cattle manure used in the experiment was air-dried and shaded, passed through a 4-mm mesh sieve and was sampled for determination of moisture, $\mathrm{pH}$ and chemical composition, on a dry basis (Tedesco et al. 1995) (Table 2).

The soil density was determined, and portions equivalent to $5.0 \mathrm{dm}^{3}$ of soil were weighed and received dolomitic limestone to raise the initial soil base saturation $(\mathrm{V})$ to $60 \%$, while the tanned manure doses were set according to the treatments. After mixing the limestone and organic fertilizer with each soil portion, they were transferred to $5.5-\mathrm{dm}^{3}$ pots, moistened at $70 \%$ of the field capacity and remained in incubation for 30 days. During incubation, the moisture was controlled every two days, in order to maintain the soil moisture at about $70 \%$ of the field capacity.

After incubation, each pot received a nonconventional vegetable seedling, according to the treatments. The seedlings used in the experiment came from the germplasm collection of non-conventional vegetables owned by the Universidade Federal de

Table 1. Initial chemical analysis of the soil used in the experiment.

\begin{tabular}{|c|c|c|c|c|c|c|c|c|c|c|c|}
\hline $\begin{array}{c}\mathrm{OM} \\
\mathrm{g} \mathrm{dm}^{-3}\end{array}$ & $\begin{array}{c}\mathrm{pH} \\
\left(\mathrm{CaCl}_{2}\right)\end{array}$ & $\begin{array}{c}\mathrm{P} \\
\mathrm{mg} \mathrm{dm^{-3 }}\end{array}$ & $\mathrm{K}^{+}$ & $\mathrm{Ca}^{2+}$ & $\mathrm{Mg}^{2+}$ & $\begin{array}{c}\mathrm{Al}^{3+} \\
\mathrm{mmol}_{\mathrm{c}} \mathrm{d}\end{array}$ & $\mathrm{H}+\mathrm{Al}$ & SB & CEC & $\mathrm{V}$ & $\mathrm{m}$ \\
\hline 35 & 4.5 & 34 & 4.2 & 19 & 6 & 4 & 64 & 29 & 93 & 31 & 12 \\
\hline
\end{tabular}

OM: organic matter; P: extracted by Mehlich; $\mathrm{H}+\mathrm{Al}$ : potential acidity; $\mathrm{SB}$ : sum of bases; $\mathrm{CEC}$ : cation exchange capacity at $\mathrm{pH} 7.0$; $\mathrm{V}$ : base saturation; $\mathrm{m}$ : $\mathrm{Al}{ }^{3+}$ saturation. 
Table 2. Moisture, $\mathrm{pH}$ and chemical composition, on a dry basis, of the cattle manure used in the experiment.

\begin{tabular}{|c|c|c|c|c|c|c|c|}
\hline $\begin{array}{c}\text { Moisture } \\
\% \\
\end{array}$ & $\begin{array}{c}\mathrm{pH} \\
\left(\mathrm{CaCl}_{2}\right)\end{array}$ & $\mathrm{C}$ & $\mathrm{N}$ & $\mathrm{C} / \mathrm{N}$ ratio & $\mathrm{P}$ & $\begin{array}{c}\mathrm{K} \\
\mathrm{g} \mathrm{kg}^{-1} \\
\end{array}$ & $\mathrm{Ca}$ \\
\hline 6.3 & 7.9 & 127 & 7 & 18 & 3 & 7 & 4 \\
\hline $\mathrm{Mg}$ & $\mathrm{S}-\mathrm{SO}_{4}{ }^{2-}$ & B & $\mathrm{Cu}$ & $\begin{array}{l}\mathrm{Fe} \\
\mathrm{mg} \mathrm{kg}{ }^{-1}\end{array}$ & $\mathrm{Mn}$ & & \\
\hline 2 & 2 & 101 & 19 & 32.202 & 219 & & \\
\hline
\end{tabular}

Lavras. The $R$. acetos $a$ and $S$. byzantina seedlings were obtained from clumps of parent plants and transplanted directly into the pots. The L. canadensis seedlings were obtained after propagation by indirect sowing in trays of 128 cells and transferred to the pots after one month of formation, when they had four definitive leaves.

The experiment was conducted for 90 days after the transplantation. The soil moisture in the pots was periodically controlled, manually, by replacing the lost water, in order to maintain the soil moisture in each pot at about $70 \%$ of the field capacity. During the conduction of the experiment, the mineral fertilization complementary to the organic fertilization of the treatments was not performed.

At the harvest time, the following parameters were evaluated for each plant: stem diameter; total number of leaves; number of leaves with commercial standard (i.e., leaves larger than $10 \mathrm{~cm}$ for R. acetosa, $8 \mathrm{~cm}$ for $S$. byzantina and $20 \mathrm{~cm}$ for L. canadensis; Brasil 2010); and production of shoot fresh matter. Subsequently, the plant shoot was washed and dried in a forced air oven at about $65{ }^{\circ} \mathrm{C}$, until constant weight, for obtening the shoot dry matter.

The shoot dry matter was ground in a Willey mill, and the samples were evaluated for chemical composition by determining the concentration of macro (N, P, K, Ca, $\mathrm{Mg}$ and $\mathrm{S}$ ) and micronutrients (B, Cu, Fe, Mn and $\mathrm{Zn}$ ) (Carmo et al. 2000). The nutrient accumulation in the plant shoot was obtained by multiplying the values of dry matter and concentration of nutrients in the shoot.

The obtained results were subjected to analysis of variance, using the F test. Subsequently, they were subjected to the means comparison test (Tukey; $\mathrm{p}<0.05$ ) and polynomial regression, using the Agroestat software (Barbosa \& Maldonado Júnior 2015).

\section{RESULTS AND DISCUSSION}

The organic fertilization with cattle manure influenced $(p<0.01)$ all the growth parameters of the non-conventional vegetables studied (stem diameter, number of leaves with commercial standard, shoot fresh and dry matter), except for the total number of leaves. There was a significant difference in growth parameters among the non-conventional vegetable species, since they have intrinsic characteristics. For stem diameter and number of commercial leaves, there was a significant interaction between the cattle manure doses and non-conventional vegetable species.

There was a linear increase in stem diameter for $S$. byzantina $\left(\mathrm{E}_{2}\right)$ with the cattle manure doses. For L. canadensis $\left(\mathrm{E}_{3}\right)$, the effect was quadratic, with an increase in stem diameter up to an estimated dose of $10.5 \mathrm{tha}^{-1}$. However, R. acetosa $\left(\mathrm{E}_{1}\right)$ showed no changes in stem diameter with the organic fertilization, and the average value obtained was $30.3 \mathrm{~mm}$ (Figure 1A).

There was a linear increase in the number of leaves with commercial standard for $S$. byzantina $\left(\mathrm{E}_{2}\right)$ with the cattle manure doses, and the values ranged from 12 to 19 leaves per plant, corresponding to an increase of 1.6 times, when comparing the treatment that received the highest dose of cattle manure (equivalent to $20 \mathrm{t} \mathrm{ha}^{-1}$ ) with the control, which did not receive organic fertilization (Figure 1B). In relation to $R$. acetosa $\left(\mathrm{E}_{1}\right)$ and $L$. canadensis $\left(\mathrm{E}_{3}\right)$, the leaves with commercial standard increased up to the estimated doses of 8.3 and $11.2 \mathrm{tha}^{-1}$ of cattle manure, respectively. The additions obtained in relation to the control were 1.2 and 1.5 times, with estimated values varying from 16 to 19 for $E_{1}$ and from 9 to 13 leaves per plant for $\mathrm{E}_{3}$.

The production of shoot fresh and dry matter of the three non-conventional leafy vegetables was adjusted to the linear model, as a function of organic fertilization (Figures 1C and 1D). The increases obtained for shoot fresh matter were 1.1, 1.8 and 1.3; while, for shoot dry matter, they were 1.3, 2.0 and 1.5 times, respectively for $R$. acetosa $\left(\mathrm{E}_{1}\right), S$. byzantina $\left(\mathrm{E}_{2}\right)$ and L. canadensis $\left(\mathrm{E}_{3}\right)$, when comparing the treatment that received the equivalent to $20 \mathrm{tha}^{-1}$ of 

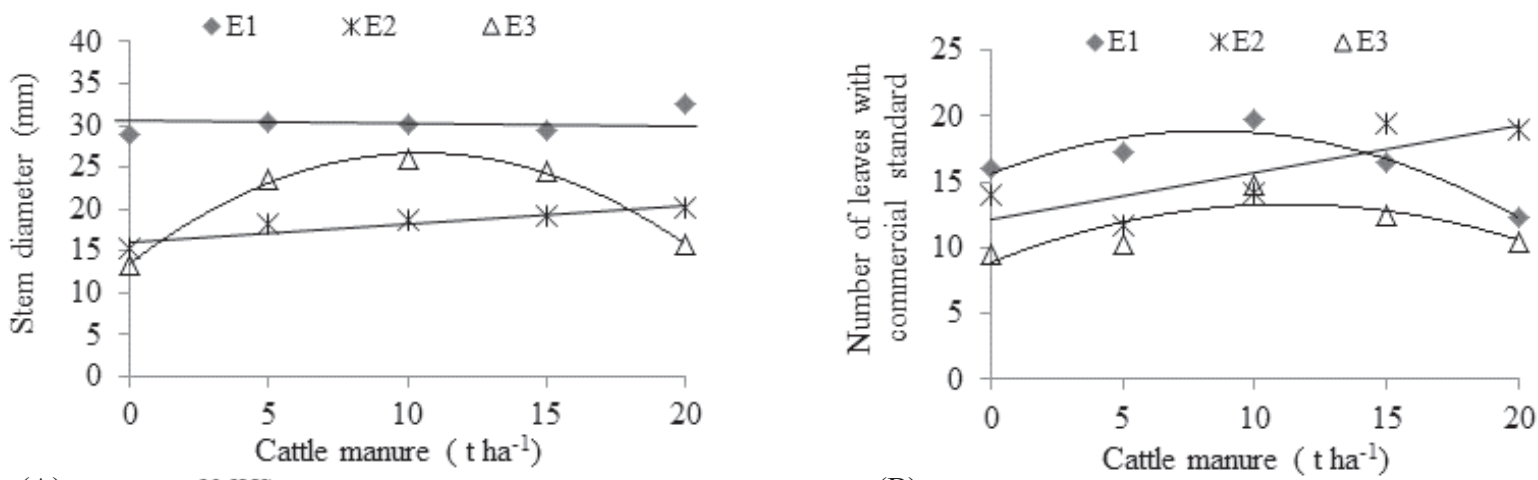

(A)

$$
\begin{aligned}
& \mathrm{y}_{E 1}=30.3 \mathrm{NS} \\
& \mathrm{y}_{\mathrm{E} 2}=0.218 \mathrm{x}+16.103 ; \mathrm{R}^{2}=0.857^{*} \\
& \mathrm{y}_{\mathrm{E} 3}=-0.120 \mathrm{x}^{2}+2.524 \mathrm{x}+13.458 ; \mathrm{R}^{2}=0.994^{* *}
\end{aligned}
$$

$$
\begin{aligned}
& \mathrm{y}_{\mathrm{E} 1}=-0.048 \mathrm{x}^{2}+0.792 \mathrm{x}+15.607 ; \mathrm{R}^{2}=0.916^{* *} \\
& \mathrm{y}_{\mathrm{E} 2}=0.355 \mathrm{x}+12.150 ; \mathrm{R}^{2}=0.686 * \\
& \mathrm{y}_{\mathrm{E} 3}=-0.035 \mathrm{x}^{2}+0.785 \mathrm{x}+8.900 ; \mathrm{R}^{2}=0.691^{* *}
\end{aligned}
$$
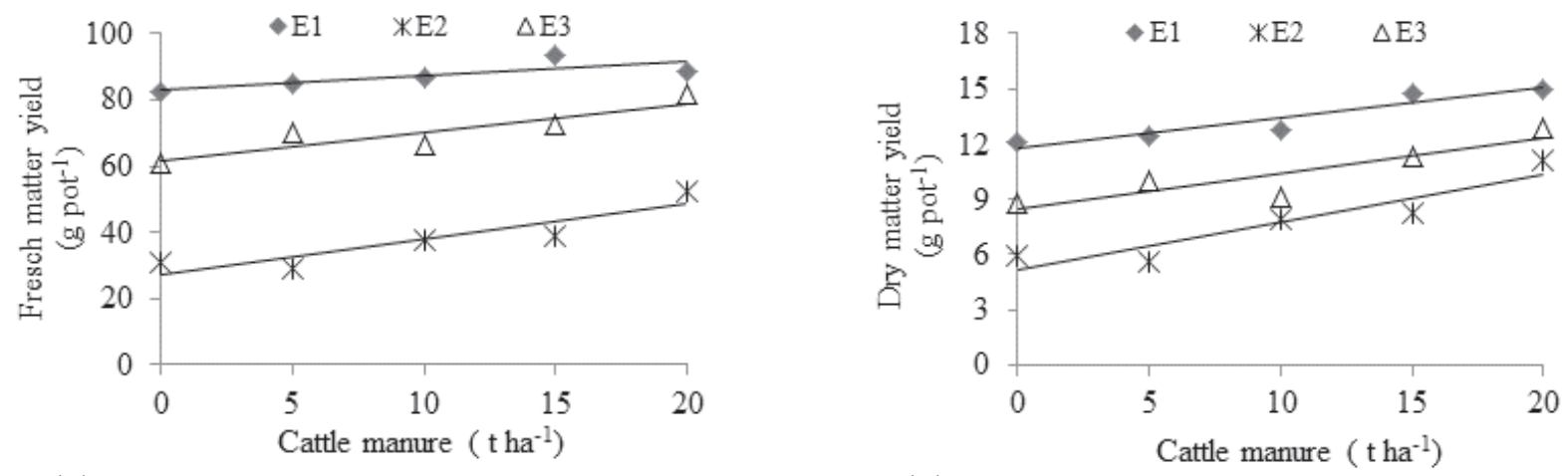

(C) $\mathrm{y}_{\mathrm{E} 1}=0.423 \mathrm{x}+82.955 ; \mathrm{R}^{2}=0.620 * *$

$\mathrm{Y}_{E 2}=1.081 \mathrm{x}+26.990 ; \mathrm{R}^{2}=0.828 * *$

$$
\begin{aligned}
& \mathrm{y}_{E 1}=0.164 \mathrm{x}+11.770 ; \mathrm{R}^{2}=0.896^{* *} \\
& \mathrm{y}_{E 2}=0.262 \mathrm{x}+5.118 ; \mathrm{R}^{2}=0.865^{* *} \\
& \mathrm{y}_{E 3}=0.193 \mathrm{x}+8.506 ; \mathrm{R}^{2}=0.804^{* *}
\end{aligned}
$$

Figure 1. Stem diameter (A), number of leaves with commercial standard (B), shoot fresh (C) and dry (D) matter of the non-conventional vegetables Rumex acetosa $\left(\mathrm{E}_{1}\right)$, Stachys byzantina $\left(\mathrm{E}_{2}\right)$ and Lactuca canadensis $\left(\mathrm{E}_{3}\right)$, as a function of fertilization with cattle manure. ${ }^{*}, * *$ and NS: significant at $5 \%(\mathrm{p}<0.05)$ and $1 \%(\mathrm{p}<0.01)$ and non-significant $(\mathrm{p}>0.05)$, respectively.

cattle manure with the control. Thus, the shoot fresh and dry matter yields varied, respectively, from 83.0 to 91.4 and from 11.8 to $15.1 \mathrm{~g}$ plant $^{-1}$ for $\mathrm{E}_{1}$, from 27.0 to 48.6 and from 5.1 to $10.4 \mathrm{~g} \mathrm{plant}^{-1}$ for $\mathrm{E}_{2}$, and from 61.7 to 79.1 and from 8.5 to $12.4 \mathrm{~g} \mathrm{plant}^{-1}$ for $\mathrm{E}_{3}$.

Non-conventional vegetables are considered more rustic and, therefore, less demanding, in relation to soil fertility conditions, than other vegetables (Viana et al. 2015). However, in this study, R. acetosa $\left(\mathrm{E}_{1}\right)$, S. byzantina $\left(\mathrm{E}_{2}\right)$ and L. canadensis $\left(\mathrm{E}_{3}\right)$ responded positively to the organic fertilization with cattle manure, in soil with an average initial condition of fertility for the cultivation of vegetables, according to the classes established by the CFSEMG (1999) and Silva et al. (2017). Silva et al. (2018a) also observed increases in the yield of S. byzantina and R. acetosa with the use of fertilizer. However, in the studies by Silva et al. (2017) and Silva et al. (2018a), mineral fertilization was used instead of the organic one.
There was no interaction between the treatments (non-conventional vegetable species and cattle manure doses), in relation to the accumulation of macronutrients in the plant shoot. The accumulated amounts of N, $\mathrm{P}, \mathrm{K}$ and $\mathrm{Ca}$ in the shoot of $R$. acetosa $\left(\mathrm{E}_{1}\right)$, S. byzantina $\left(\mathrm{E}_{2}\right)$ and L. canadensis $\left(\mathrm{E}_{3}\right)$ increased linearly with the doses of cattle manure (Figures 2A, 2B, 2C and 2D).

For $R$. acetosa $\left(\mathrm{E}_{1}\right)$, the increases obtained in relation to the accumulation of $\mathrm{N}, \mathrm{P}, \mathrm{K}$ and $\mathrm{Ca}$ in the shoot were 1.2, 1.2, 1.9 and 1.4 times, respectively, when comparing the treatment that received the highest dose of cattle manure (equivalent to $20 \mathrm{tha}^{-1}$ ) with the control treatment (without organic fertilization). In relation to $S$. byzantina $\left(\mathrm{E}_{2}\right)$, the increases observed in relation to the accumulation of $\mathrm{N}, \mathrm{P}, \mathrm{K}$ and $\mathrm{Ca}$ were 1.1, 1.2, 1.2 and 1.3 times, when comparing the extreme treatments. As for L. canadensis $\left(\mathrm{E}_{3}\right)$, the increases observed in relation 

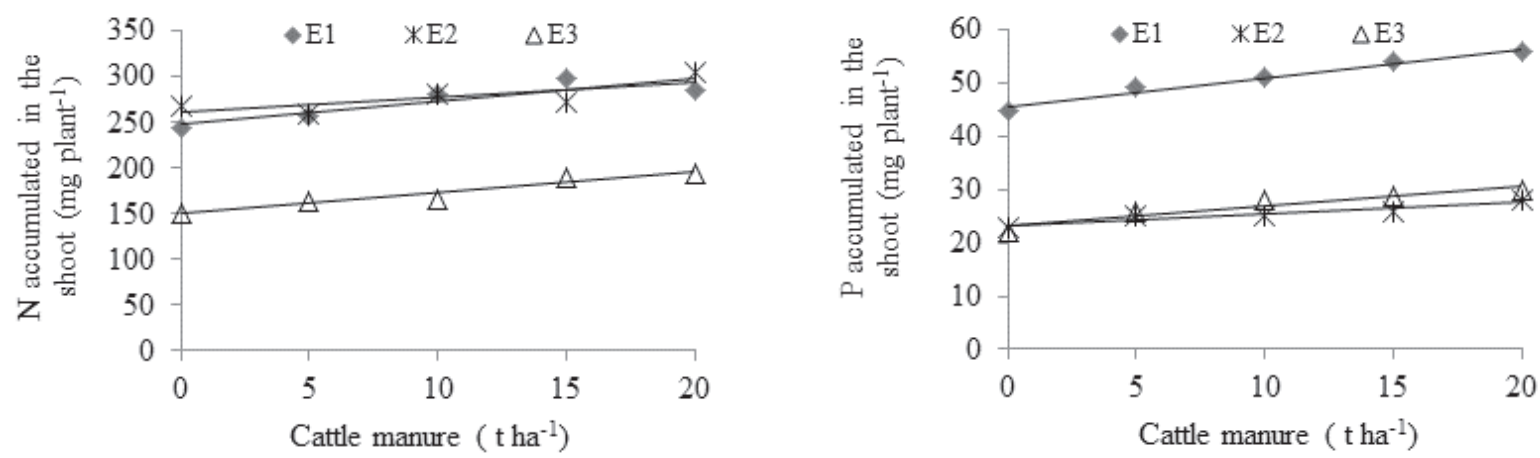

(A)

$$
\begin{aligned}
& \mathrm{y}_{E 1}=2.530 \mathrm{x}+247.400 ; \mathrm{R}^{2}=0.810^{* * *} \\
& \mathrm{y}_{E 2}=1.690 \mathrm{x}+260.350 ; \mathrm{R}^{2}=0.622^{*} \\
& \mathrm{y}_{\mathrm{E} 3}=2.280 \mathrm{x}+150.050 ; \mathrm{R}^{2}=0.930^{* *}
\end{aligned}
$$

$$
\begin{aligned}
& \mathrm{y}_{E 1}=0.520 \mathrm{x}+45.750 ; \mathrm{R}^{2}=0.977^{* *} \\
& \mathrm{y}_{E 2}=0.220 \mathrm{x}+23.200 ; \mathrm{R}^{2}=0.917^{* *} \\
& \mathrm{y}_{E 3}=0.380 \mathrm{x}+23.200 ; \mathrm{R}^{2}=0.903^{* *}
\end{aligned}
$$
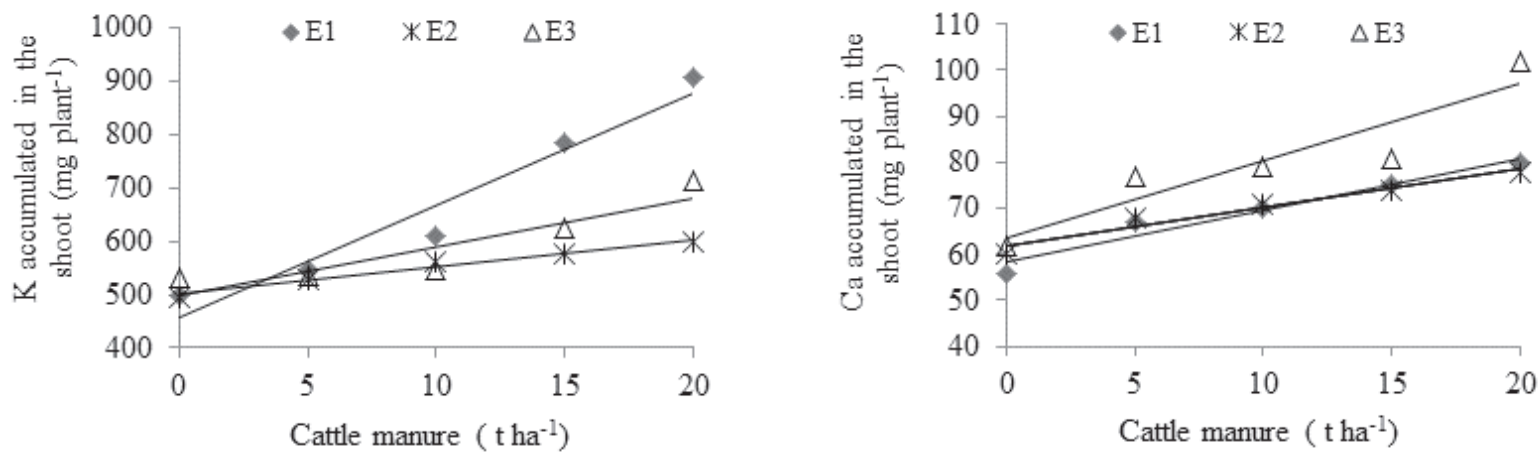

(C) $\mathrm{y}_{\mathrm{E} 1}=21.100 \mathrm{x}+457.600 ; \mathrm{R}^{2}=0.948 * *$ $\mathrm{Y}_{\mathrm{E} 2}=5.140 \mathrm{x}+501.000 ; \mathrm{R}^{2}=0.971^{* *}$

(D)

$\mathrm{y}_{\mathrm{E} 1}=1.120 \mathrm{x}+58.400 ; \mathrm{R}^{2}=0.953 * *$ $\mathrm{y}_{\mathrm{E} 2}=0.840 \mathrm{x}+61.800 ; \mathrm{R}^{2}=0.955 * *$ $\mathrm{Y}_{E 3}=9.080 \mathrm{x}+499.800 ; \mathrm{R}^{2}=0.824^{* *}$ $\mathrm{Y}_{\mathrm{E} 3}=1.680 \mathrm{x}+63.400 ; \mathrm{R}^{2}=0.862^{* *}$

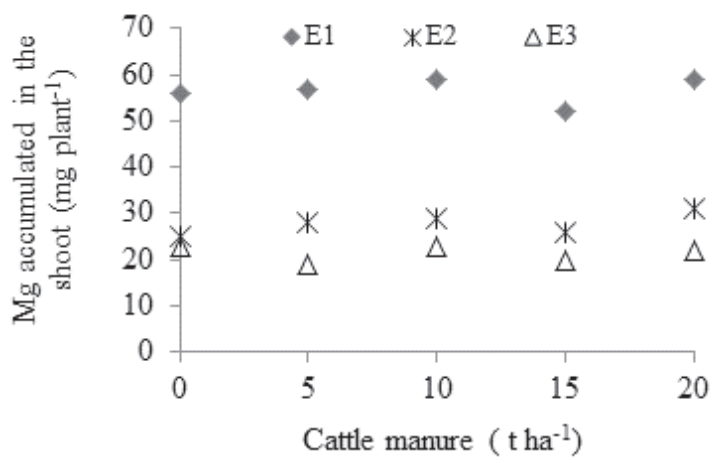

(E) $\quad \mathrm{y}_{\mathrm{E} 1}=57 \mathrm{NS}$ $\mathrm{y}_{E 2}=2 \mathrm{NS}$
$\mathrm{y}_{E 3}=21 \mathrm{NS}$

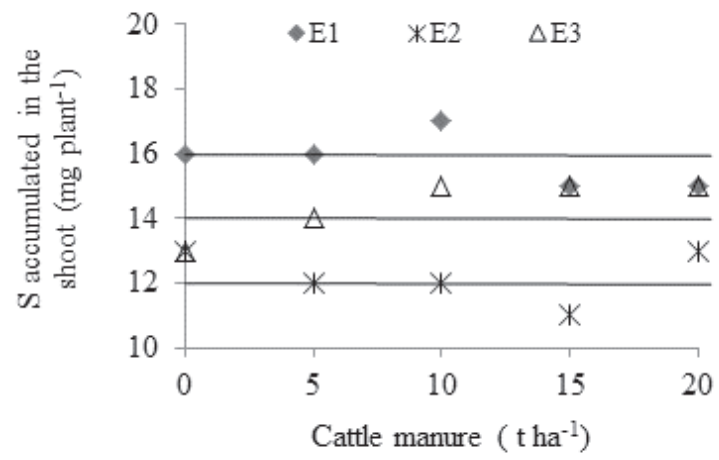

(F)

$$
\begin{aligned}
& \mathrm{y}_{\mathrm{E} 1}=16 \mathrm{NS} \\
& \mathrm{y}_{\mathrm{E} 2}=12 \mathrm{NS} \\
& \mathrm{y}_{\mathrm{E} 3}=14 \mathrm{NS}
\end{aligned}
$$

Figure 2. Accumulated amounts of the macronutrients N (A), P (B), K (C), Ca (D), Mg (E) and S (F) in the shoot of Rumex acetosa $\left(\mathrm{E}_{1}\right)$, Stachys byzantina $\left(\mathrm{E}_{2}\right)$ and Lactuca canadensis $\left(\mathrm{E}_{3}\right)$, as a result of fertilization with cattle manure. * ** and NS: significant at $5 \%(\mathrm{p}<0.05)$ and $1 \%(\mathrm{p}<0.01)$ and non-significant $(\mathrm{p}>0.05)$, respectively.

to the accumulation of these macronutrients were $1.3,1.3,1.4$ and 1.5 times. Thus, the accumulated amounts of N, P, K and $\mathrm{Ca}$ in the shoot of the species varied, respectively, from 247 to 298,46 to 56,458 to 880 and 58 to $81 \mathrm{mg} \mathrm{plant}^{-1}$ for $\mathrm{E}_{1}$; from 260 to 294 , 23 to 28,501 to 604 and 62 to $79 \mathrm{mg} \mathrm{plant}^{-1}$ for $\mathrm{E}_{2}$; and from 150 to 196, 23 to 31,500 to 681 and 63 to $97 \mathrm{mg} \mathrm{plant}^{-1}$ for $\mathrm{E}_{3}$.

The accumulated amounts of $\mathrm{Mg}$ and $\mathrm{S}$ in the shoot did not vary with the organic fertilization, and the mean values obtained were 57 and 16, 28 and 12 , and 21 and $14 \mathrm{mg} \mathrm{plant}^{-1}$, respectively for 
$R$. acetosa $\left(\mathrm{E}_{1}\right), S$. byzantina $\left(\mathrm{E}_{2}\right)$ and $L$. canadensis $\left(\mathrm{E}_{3}\right)$ (Figures $1 \mathrm{E}$ and $1 \mathrm{~F}$ ).

The improvement in the soil fertility conditions, particularly in relation to the increase in the availability of $\mathrm{N}, \mathrm{P}, \mathrm{K}$ and $\mathrm{Ca}$ with the organic fertilization, possibly explains the increase in the accumulated amounts of these macronutrients in the shoot of the non-conventional vegetables studied.
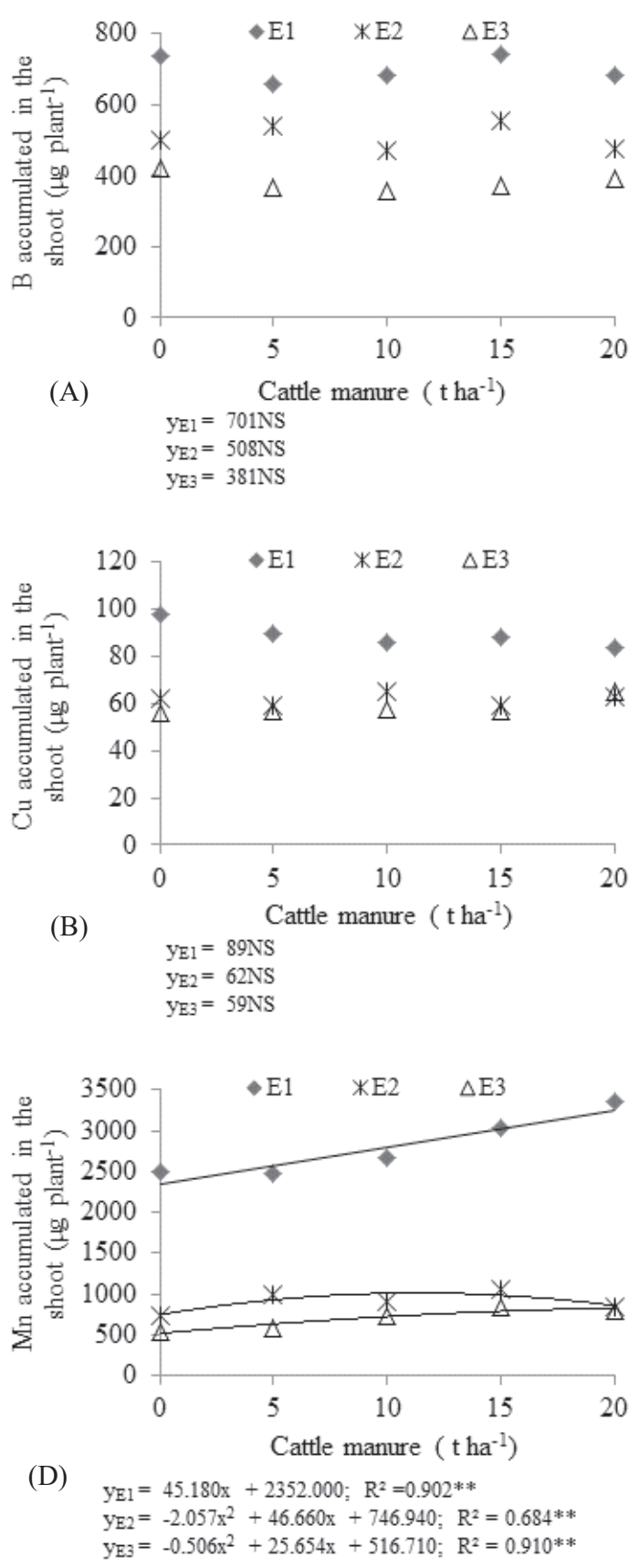

There was a significant effect $(p<0.01)$ of the fertilization with cattle manure on the accumulated amounts of the micronutrients $\mathrm{Fe}, \mathrm{Mn}$ and $\mathrm{Zn}$ in the shoot of the non-conventional vegetables. However, the accumulated amounts of $\mathrm{B}$ and $\mathrm{Cu}$ in the plant shoot did not change $(p>0.05)$ with the organic fertilization. The accumulation of micronutrients in the shoots varied significantly $(\mathrm{p}<0.01)$, according to the plant species. There was an interaction $(\mathrm{p}<0.01)$ of the treatments only in relation to the accumulation of $\mathrm{Fe}$ and $\mathrm{Zn}$ in the plant shoot.

The accumulated amounts of $\mathrm{Fe}$ and $\mathrm{Mn}$ in the shoot of $R$. acetosa $\left(\mathrm{E}_{1}\right)$ and Fe in S. byzantina $\left(E_{2}\right)$ increased linearly with the organic fertilization. In these cases, the values ranged from 3,318 to 6,$551 ; 2,352$ to 3,256 ; and 3,317 to $7,068 \mu$ g plant $^{-1}$, respectively, corresponding to increases of 2.0, 1.4 and 2.1 times, when comparing the treatment that received the equivalent to $20 \mathrm{t} \mathrm{ha}^{-1}$ of cattle manure with the control (Figures 3C and 3D).
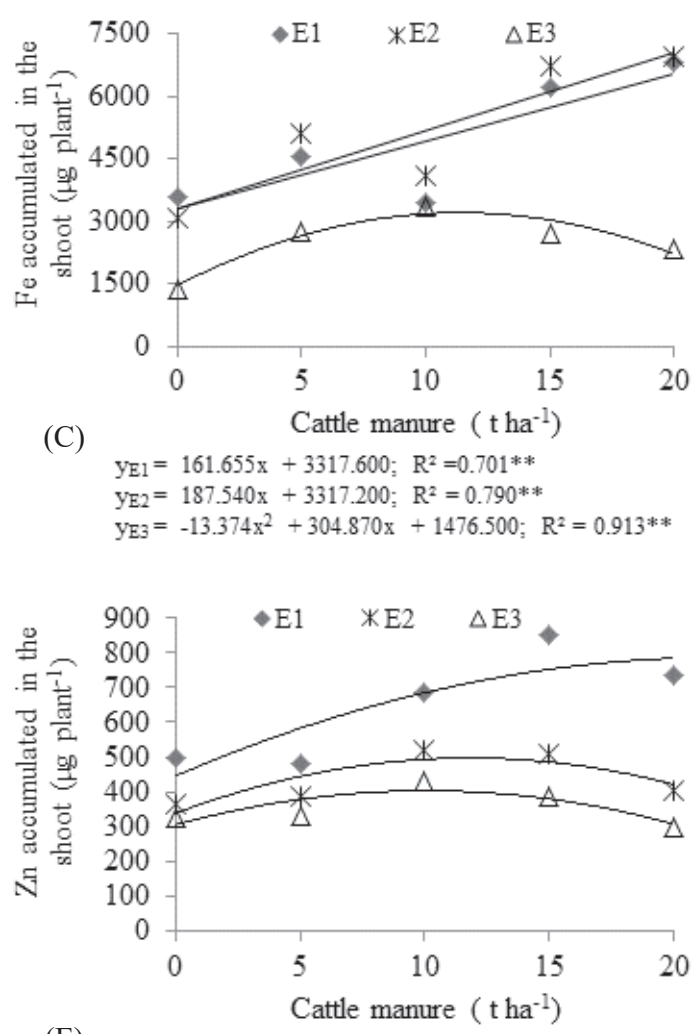

(E)

$$
\begin{array}{ll}
\mathrm{y}_{E 1}=-0.700 \mathrm{x}^{2}+30.940 \mathrm{x}+445.600 ; & \mathrm{R}^{2}=0.746 * * \\
\mathrm{y}_{E 2}=-1.134 \mathrm{x}^{2}+26.826 \mathrm{x}+338.090 ; & \mathrm{R}^{2}=0.753^{* *} \\
\mathrm{y}_{\mathrm{E} 3}=-0.966 \mathrm{x}^{2}+19.434 \mathrm{x}+304.710 ; & \mathrm{R}^{2}=0.709 * *
\end{array}
$$

Figure 3. Accumulated amounts of the micronutrients B (A), Cu (B), Fe (C), Mn (D) and $\mathrm{Zn}(\mathrm{E})$ in the shoot of the non-conventional vegetables Rumex acetosa $\left(\mathrm{E}_{1}\right)$, Stachys byzantina $\left(\mathrm{E}_{2}\right)$ and Lactuca canadensis $\left(\mathrm{E}_{3}\right)$, as a result of fertilization with cattle manure. $* *$ and NS: significant at $1 \%(\mathrm{p}<0.01)$ and non-significant $(\mathrm{p}>0.05)$, respectively. 
In relation to the Mn accumulation in the shoot of S. byzantina $\left(\mathrm{E}_{2}\right)$ and $\mathrm{Fe}$ and $\mathrm{Mn}$ in L. canadensis $\left(\mathrm{E}_{3}\right)$, the results adjusted to the quadratic model, and the observed increases were, respectively, 1.1, 1.5 and 1.6 times, when comparing the extreme treatments. As a result, the variation in values ranged from 747 to $857 ; 1,477$ to 2,224 ; and 517 to $827 \mu$ plant $^{-1}$, respectively.

For $\mathrm{Zn}$, the amounts accumulated in the shoot of $R$. acetosa $\left(\mathrm{E}_{1}\right), S$. byzantina $\left(\mathrm{E}_{2}\right)$ and $L$. canadensis $\left(\mathrm{E}_{3}\right)$ increased up to the estimated doses of 20.0, 11.8 and $10.1 \mathrm{t} \mathrm{ha}^{-1}$ of cattle manure, respectively, with values ranging from 446 to 784,338 to 421 and 305 to $491 \mu$ g plant $^{-1}$ (Figure 3E).

Among the non-conventional vegetable species studied, $R$. acetosa $\left(\mathrm{E}_{1}\right)$ showed a greater accumulation of most nutrients $(\mathrm{P}, \mathrm{K}, \mathrm{Mg}, \mathrm{S}, \mathrm{B}, \mathrm{Cu}$, $\mathrm{Mn}$ and $\mathrm{Zn}$ ) than S. byzantina $\left(\mathrm{E}_{2}\right)$ and L. canadensis $\left(E_{3}\right)$, what shows that it has a higher demand for nutrients than the others (Figure 4).

In relation to $\mathrm{N}$ and $\mathrm{Fe}, R$. acetos $a$ and $S$. byzantina presented similar and superior accumulations, in relation to $L$. canadensis. However, the accumulated amount of $\mathrm{Ca}$ in $L$. canadensis plants was higher than in the others. Considering the
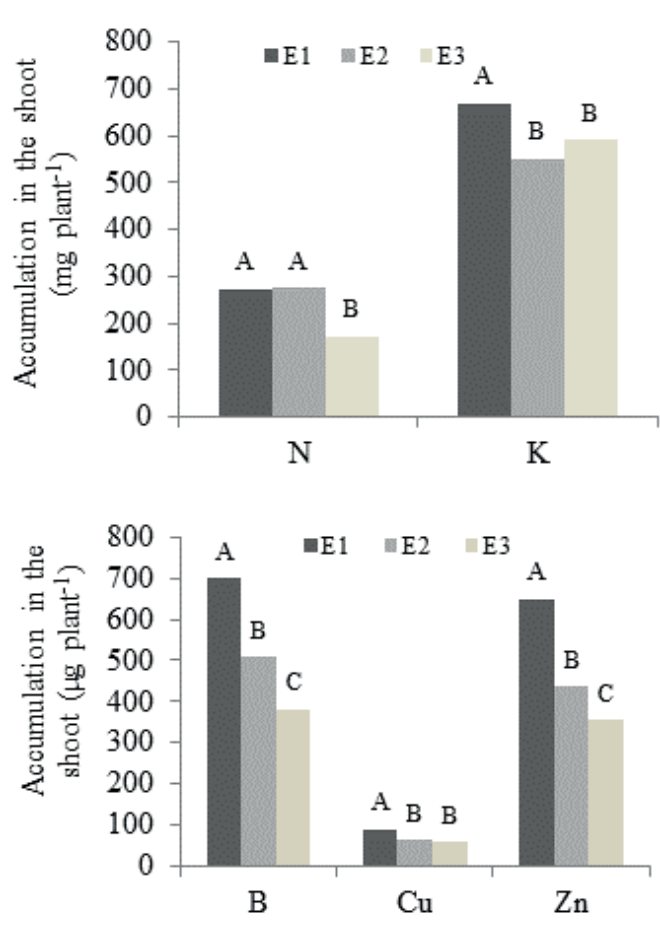

non-conventional vegetables evaluated, in general, the following increasing sequence of nutrient accumulation in the shoot was obtained: $\mathrm{K}>\mathrm{N}>$ $\mathrm{Ca}>\mathrm{Mg}>\mathrm{P}>\mathrm{S}$ for macronutrients, as well as $\mathrm{Fe}>$ $\mathrm{Mn}>\mathrm{B}>\mathrm{Zn}>\mathrm{Cu}$ for micronutrients.

In relation to the concentration of nutrients in the shoot of $R$. acetosa, S. byzantina and L. canadensis, the values obtained for the treatment that received the highest dose of cattle manure were, respectively, 23, 33 and $25 \mathrm{~g} \mathrm{~kg}^{-1}$ of $\mathrm{N} ; 5,3$ and $3 \mathrm{~g} \mathrm{~kg}^{-1}$ of P; 73, 56 and $59 \mathrm{~g} \mathrm{~kg}^{-1}$ of K; 5,8 and $10 \mathrm{~g} \mathrm{~kg}^{-1}$ of $\mathrm{Ca} ; 4,4$ and $3 \mathrm{~g} \mathrm{~kg}^{-1}$ of $\mathrm{Mg} ; 1,2$ and $2 \mathrm{~g} \mathrm{~kg}^{-1}$ of S; 56, 48 and $39 \mathrm{mg} \mathrm{kg}^{-1}$ of $\mathrm{B} ; 7,7$ and $7 \mathrm{mg} \mathrm{kg}^{-1}$ of Cu ; 548,529 and $345 \mathrm{mg} \mathrm{kg}^{-1}$ of Fe; 198 , 109 and $98 \mathrm{mg} \mathrm{kg}^{-1}$ of Mn; 42, 47 and $37 \mathrm{mg} \mathrm{kg}^{-1}$ of $\mathrm{Zn}$. These values, except for $\mathrm{Mn}$ and $\mathrm{Fe}$, are within the nutrient concentration range considered suitable for conventional leafy vegetables such as lettuce, endive, chicory, spinach and arugula (Trani et al. 2014).

The concentrations of $\mathrm{Mn}$ and $\mathrm{Fe}$ in the studied non-conventional vegetables are above those normally found in leafy vegetables (Trani et al. 2014). These results corroborate those obtained by Silva et al. (2017), Silva et al. (2018a) and Botrel
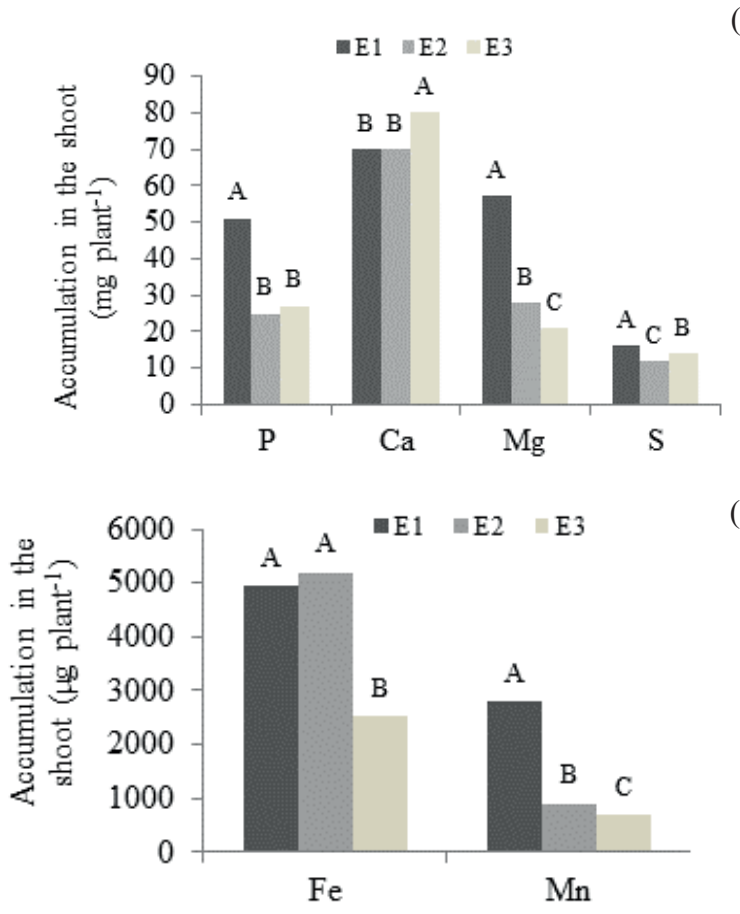

Figure 4. Average accumulation of the macronutrients $\mathrm{N}$ and $\mathrm{K}(\mathrm{A})$; $\mathrm{P}, \mathrm{Ca}, \mathrm{Mg}$ and $\mathrm{S}(\mathrm{B})$; and the micronutrients $\mathrm{B}, \mathrm{Cu}$ and $\mathrm{Zn}(\mathrm{C})$; $\mathrm{Fe}$ and $\mathrm{Mn}(\mathrm{D})$, in the shoot of Rumex acetosa $\left(\mathrm{E}_{1}\right)$, Stachys byzantina $\left(\mathrm{E}_{2}\right)$ and Lactuca canadensis $\left(\mathrm{E}_{3}\right)$. The same letters for each evaluated nutrient do not differ by the Tukey test $(\mathrm{p}>0.05)$. 
et al. (2020), who also found high concentrations of nutrients in non-conventional vegetables, particularly in relation to Fe.

Nutritional deficiencies, such as of $\mathrm{Fe}$ and $\mathrm{Zn}$, are frequent in the population (Possobom et al. 2015, Oliveira et al. 2016), and the studied nonconventional vegetables may be a good source of nutrients for the population diet, especially that of low income, being an alternative to food security. Regarding organic fertilization, according to most the results obtained in this study, it seems that the dose of $20 \mathrm{tha}^{-1}$ of cattle manure is the most suitable one for the non-conventional vegetables $R$. acetosa, $S$. byzantina and L. canadensis.

\section{CONCLUSIONS}

1. Organic fertilization with cattle manure increases the production and accumulation of nutrients in the non-conventional vegetables Rumex acetosa, Stachys byzantina and Lactuca canadensis;

2. R. acetosa has a greater nutrient accumulation than $S$. byzantina and L. canadensis.

\section{REFERENCES}

ALENCAR, T. L.; CHAVES, A. K.; SANTOS, C. L. A.; ASSIS JÚNIOR, R. N.; MOTA, J. C. A. Atributos físicos de um cambissolo cultivado e tratado com biofertilizante na chapada Apodi, Ceará. Revista Brasileira de Ciência do Solo, v. 39, n. 3, p. 737-749, 2015.

BARBOSA, J. C.; MALDONADO JÚNIOR, W. Experimentação agronômica e AgroEstat: sistema para análises estatísticas de ensaios agronômicos. Jaboticabal: Multipress, 2015.

BOTREL, N.; FREITAS, S.; FONSECA M. J. O.; MELO, R. A. C.; MADEIRA, N. Valor nutricional de hortaliças folhosas não convencionais cultivadas no bioma Cerrado. Brazilian Journal of Food Technology, v. 23, e2018174, 2020.

BRAOS, L. B.; CRUZ, M. C. P.; FERREIRA, M. E.; KUHNEN, F. Organic phosphorus fractions in soil fertilized with cattle manure. Revista Brasileira de Ciência do Solo, v. 39, n. 1, p. 140-150, 2015.

BRASIL. Hortaliças não-convencionais (tradicionais). Brasília, DF: Ministério da Agricultura, Pecuária e Abastecimento, 2010.

CARMO, C. A. F. S.; ARAUJO, W. S.; BERNARDI, A. C. C.; SALDANHA, M. F. C. Métodos de análise de tecidos vegetais utilizados na Embrapa Solos. Rio de Janeiro: Embrapa Solos, 2000. (Circular técnica, 6).

COMISSÃO DE FERTILIDADE DO SOLO DO ESTADO DE MINAS GERAIS (CFSEMG). Recomendações para o uso de corretivos e fertilizantes em Minas Gerais. Viçosa: UFV, 1999.

KINUPP, V. F.; BARROS, I. B. I. Teores de proteínas e minerais em espécies nativas, potenciais hortaliças e frutas. Ciência e Tecnologia de Alimentos, v. 28, n. 4, p. 846-857, 2008.

KINUPP, V. F.; LORENZI, H. Plantas alimentícias não convencionais (PANC) no Brasil: guia de identificação, aspectos nutricionais e receitas ilustradas. Nova Odessa: Instituto Plantarum, 2014.

MANTOVANI, J. R.; CARRERA, M.; MOREIRA, J. L. A.; MARQUES, D. J.; SILVA, A. B. Fertility properties and leafy vegetable production in soils fertilized with cattle manure. Revista Caatinga, v. 30, n. 4, p. 825-836, 2017.

OLIVEIRA, L. C. P.; SOUZA, D. C.; SILVA, L. F. L.; RESENDE, L. V.; SILVA, M. L. S.; GUERRA, T. S. Silicate fertilization in non-conventional vegetables in the southern region of Minas Gerais in Brazil. Revista Ceres, v. 66, n. 6 , p. $470-478,2019$.

OLIVEIRA, L. C. P.; SOUZA, D. C.; SILVA, L. F. L.; RESENDE, L. V.; SILVA, M. L. S.; GUERRA, T. S. Effect of silica fertilization on unconventional vegetables. Revista de Ciências Agroveterinárias, v. 19, n. 2, p. 224-229, 2020.

OLIVEIRA, N. P.; FAQUIN, V.; COSTA, A. L.; LIVRAMENTO, K. G.; PINHO, P. J.; GUILHERME, L. R. G. Genotypic variation of agronomic traits as well as concentration of $\mathrm{Fe}, \mathrm{Zn}, \mathrm{P}$ and phytate in soybean cultivars. Revista Ceres, v. 63, n. 3, p. 403-411, 2016.

PADILHA JÚNIOR, M. C. P.; DONATO, S. L. R.; DONATO, P. E. R.; SILVA, J. A. Atributes of the soil with cactus pear under organic fertilization, diferent spacings and sampling times. Revista Brasileira de Engenharia Agrícola e Ambiental, v. 24, n. 7, p. 444-450, 2020.

PEIXOTO FILHO, J. U.; FREIRE, M. B. G. S.; FREIRE, F. J.; MIRANDA, M. F. A.; PESSOA, L. G. M.; KAMIMURA, K. M. Produtividade de alface com doses de esterco de frango, bovino e ovino em cultivos sucessivos. Revista Brasileira de Engenharia Agrícola e Ambiental, v. 17, n. 4, p. 419-424, 2013.

POSSOBOM, M. T.D. F.; RIBEIRO, N. D.; DOMINGUES, L. S.; CASAGRANDE, C. R. Genetic control of iron concentration in Mesoamerican and Andean common bean seeds. Pesquisa Agropecuária Brasileira, v. 50, n. 5, p. 383-391, 2015. 
RAIJ, B. V.; CANTARELla, H.; QUAGGIO, J. C.; FURLANI, A. M. C. Recomendações de adubação e calagem para o estado de São Paulo. 2. ed. Campinas: Instituto Agronômico, 1997. (Boletim técnico, 100).

SILVA, F. C. Manual de análises químicas de solos, plantas e fertilizantes. 2. ed. rev. atual. Brasília, DF: Embrapa Informação Tecnológica, 2009.

SILVA, L. F. L.; SOUZA, D. C.; RESENDE, L. V.; GONÇALVES, W. M.; PEREIRA, T. A.; VIEIRA, S. D. Nutrição mineral, densidade de plantio, caracterização biométrica e fenológica de Rumex acetosa L. Revista de Ciências Agrárias, v. 41, n. 1, p. 129-137, 2018 a.

SILVA, L. F. L.; SOUZA, D. C.; RESENDE, L. V.; GONÇALVES, W. M.; COSTA, G. M.; MARTINS, I. A. Mineral nutrition, planting density, biometric and phenological characterization of the Stachys byzantina. Magistra, v. 29, n. 2, p. 192-199, 2017.

SILVA, L. F. L.; SOUZA, D. C.; RESENDE, L. V.; NASSUR, R. C. M. R.; SAMARTINI, C. Q.; GONÇALVES, W. M. Nutritional evaluation of nonconventional vegetables in Brazil. Anais da Academia Brasileira de Ciência, v. 90, n. 2, p. 1775-1787, 2018 b.

SILVA, L. F. L.; SOUZA, D. C.; XAVIER, J. B.; SAMARTINI, C. Q.; RESENDE, L. V. Avaliação nutricional de caruru (Amaranthus spp.). Agrarian, v. 12, n. 2, p. 411-417, 2019.
SOUZA, D. C.; SILVA, L. F. L.; RESENDE, L. V.; COSTA, P. A.; GUERRA, T. S.; GONCALVES, W. M. Influence of irrigation, planting density and vegetative propagation on yield of rhizomes of arrowroot starch. Revista de Ciências Agrárias, v. 41, n. 3, p. 683-691, 2018.

TEDESCO, M. J.; GIANELLO, C.; BISSANI, C. A.; BOHNEN, H.; VOLKWEISS, S. J. Análise de solo, plantas e outros materiais. 2. ed. Porto Alegre: UFRGS, 1995.

TRANI, P. E.; PURQUÉRIO, L. F. V.; FIGUEIREDO, G. J. B.; TIVELLI, S. W.; BLAT, S. F. Calagem e adubação da alface, almeirão, agrião d'água, chicória, coentro, espinafre e rúcula. Campinas: Instituto Agronômico, 2014.

VIANA, M. M. S.; CARLOS, L. A.; SILVA, E. C.; PEREIRA, S. M. F.; OLIVEIRA, D. B.; ASSIS, M. L. V. Composição fitoquímica e potencial antioxidante de hortaliças não convencionais. Horticultura Brasileira, v. 33, n. 4 , p. 504-509, 2015.

XAVIER, J. B.; CASTRO, D. G.; SILVA, D. M.; ABREU, R. A. A.; SOUZA, D. C.; SILVA, M. L. S. Eficiência de absorção de nutrientes em Amaranthus spp. Magistra, v. 30, n. 1, p. 199-210, 2019.

YAGI, R.; NAZARENO, N. R. X.; KAWAKAMI, J. Poultry litter and fresh mulch of elephant grass improve the organic potato production. Pesquisa Agropecuária Tropical, v. 50, e57585, 2020. 